\title{
Le palanquin d'argent de l'inca : petite enquête d'ethno-histoire à propos d'un objet absent
}

Thérèse Bouysse-Cassagne

\section{(2) OpenEdition}

\section{Journals}

Édition électronique

URL : https://journals.openedition.org/tc/446

DOI : $10.4000 /$ tc. 446

ISSN : 1952-420X

Éditeur

Éditions de l'EHESS

\section{Édition imprimée}

Date de publication : 1 mai 1998

ISSN : 0248-6016

\section{Référence électronique}

Thérèse Bouysse-Cassagne, « Le palanquin d'argent de l'inca : petite enquête d'ethno-histoire à propos d'un objet absent », Techniques \& Culture [En ligne], 29 | 1998, mis en ligne le 28 octobre 2005, consulté le 29 septembre 2022. URL : http://journals.openedition.org/tc/446 ; DOI : https://doi.org/10.4000/tc. 446

Ce document a été généré automatiquement le 29 septembre 2022.

Tous droits réservés 
Le palanquin d'argent de l'inca : petite enquête d'ethno-histoire à propos d'un objet absent

Thérèse Bouysse-Cassagne 